\title{
CHANGE OF ECOLOGICAL AND BIOLOGICAL PROPERTIES OF CESPITOSE AND PODSOLIC SOIL AT BINOMIAL DEPOSITS EXPOSED TO LOCAL WILD FIRE
}

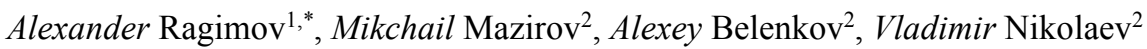 \\ ${ }^{1}$ Vladimir State University named after A.G. and N.G. Stoletov, Vladimi, Russia \\ ${ }^{2}$ Moscow Academy of Agricultural Sciences named after Timiryazev, Moscow, Russia
}

\begin{abstract}
The article deals with the ground wild fire impact on physical and chemical and ecological and biological condition of cespitose and podsolic soils on binomial deposits of the Meshcherska province of Gus-Khrustalny district, the Vladimir region under different forest cultures type. In the course of the study, a clear differentiation of changes in the microbiological pool of sod-podzolic soil on bicompartmental deposits under different types of forests was established. The quantitative composition of ammonia factors after exposure to pyrogenic exposure decreased on the sod-podzolic soil of coniferous forests, while the number of photographers, mushrooms, and oligotrophs sharply decreases in the area of pyrogenic exposure in the mixed forest. Within the territory exposed to fire, there is a decrease in the content of organic matter, as well as the content of other biophilic elements. The physical properties of sod-podzolic soil on bicompartmental deposits are also subject to change, in the direction of significant deterioration.
\end{abstract}

\section{Introduction}

The research object in this research is the sod-podzolic soil spread on the territory of Meshchora province, GusKhustalny District, Vladimir Region after direct fireinduced influence of the dead wood caused by unregulated dead wood burning near the village of Shabanovo (the central lake Meshchora, coniferous forest, the fire on April 29. 2017) grass litter burning on the area of 0.01 hectares $52 \mathrm{~km}$ to the southwest of Nikulino settlement in Gus-Khrustalny forestry (Meshchora in Gus-Khustalny District (Meshchora Gusevsko-Kolpskaya), the coniferous and broad-leaved (mixed) forest, the fire on May 2. 2017) grass litter burning on the area of 0,02 hectares.

According to a soil properties research after the fire control soil cuts were made on the background and fireinduced soils which allowed to establish type accessory of the explored soils: Near the village of Shabanovo (the fire on April 29. 2017) the soil cover is represented by sod-podzolic sandy loam gley soil on binomial deposits (on sand spread on moraine loam), and sod-podzolic sandy loam soil on binomial deposits (on thin loam, spread by sand) in Nikulino settlement in GusKhrustalny forestry (the fire on May 2. 2017) respectively.

The research program included determination of the key agrochemical, physical and chemical as well as ecological and biological parameters of the soil according to the standard procedures. The soil acid value $(\mathrm{pH})$ was determined in $\mathrm{KCl}$ extract (GOST 26483-85). Content of the labile phosphorus $\left(\mathrm{P}_{2} \mathrm{O}_{5}\right)$ and potassium
$\left(\mathrm{K}_{2} \mathrm{O}\right)$ was determined by Kirsanov's technique in modification of CINAO (Central research Institute of agrochemical service of agriculture) (GOST P 546502011). Content of organic matter (C, \%) by Tyurin's technique in modification of CINAO (GOST 26213-91).

Ammonifiers seeding and growing were carried out on meat-and-peptone agar (MPA), those of prototrophs on starch-and-ammonia agar (SAA), fungi - on Capek's agar, oligotrofs - on a selective medium. Soil samples gathering was carried out by a soil cane drill to the depth of $0-20 \mathrm{~cm}$. Sampling was made from the center in view of accurate fire impact on a soil cover. For the research carrying out 160 soil samples were taken from each the analyzed sites and the composite samples were made for a further research.

\section{Methods and objects of researches}

The research object in this research is the sod-podzolic soil spread on the territory of Meshchora province, GusKhustalny District, Vladimir Region after direct fireinduced influence of the dead wood caused by unregulated dead wood burning near the village of Shabanovo (the central lake Meshchora, coniferous forest, the fire on April 29. 2017) grass litter burning on the area of 0.01 hectares $52 \mathrm{~km}$ to the southwest of Nikulino settlement in Gus-Khrustalny forestry (Meshchora in Gus-Khustalny District (Meshchora Gusevsko-Kolpskaya), the coniferous and broad-leaved (mixed) forest, the fire on May 2. 2017) grass litter burning on the area of 0,02 hectares.

\footnotetext{
*Corresponding author: pifo@mail.ru
} 
Table 1. Soil cover chemical properties change of different forest biotopes types under the influence of a fire-induced factor.

\begin{tabular}{|c|c|c|c|c|}
\hline Province & \multicolumn{4}{|c|}{ Smolensk and Moscow province of a zone of the mixed woods (subtaiga) of East European Plain } \\
\hline Landscape area & \multicolumn{2}{|c|}{ Central lake Meshchora } & \multicolumn{2}{|c|}{$\begin{array}{l}\text { Meshchora in Gus-Khustalny District } \\
\text { (Meshchora Gusevsko-Kolpskaya) }\end{array}$} \\
\hline Soil & \multicolumn{2}{|c|}{$\begin{array}{c}\text { Sod-podzolic sandy loam gley soil on } \\
\text { binomial deposits }\end{array}$} & \multicolumn{2}{|c|}{ Sod-podzolic sandy loam soil on binomial deposits } \\
\hline Forest type & \multicolumn{2}{|c|}{ Coniferous forest } & \multicolumn{2}{|c|}{ Mixed forest } \\
\hline Index/option & Monitoring & After the fire To & Monitoring & After the fire To \\
\hline $\mathrm{pH} \mathrm{KCl}$ & 5.43 & 6.45 & 5.72 & 6.64 \\
\hline $\mathrm{C}, \%$ & 1.32 & 1.01 & 1.99 & 1.14 \\
\hline $\mathrm{P}_{2} \mathrm{O}_{5} \mathrm{mg} / \mathrm{kg}$ & 130 & 184.1 & 194.4 & 216.3 \\
\hline $\mathrm{K}_{2} \mathrm{O} \mathrm{mg} / \mathrm{kg}$ & 94.0 & 139.4 & 101.0 & 183.6 \\
\hline $\mathrm{Hr}, \mathrm{mg}$-ekv/100g. & 1.38 & 1.47 & 1.96 & 2.19 \\
\hline Ca,mg-ekv/100 g. & 2.8 & 2.94 & 2.4 & 2.51 \\
\hline $\mathrm{Mg}, \mathrm{mg}-\mathrm{kv} / 100 \mathrm{~g}$. & 2.1 & 2.32 & 2.2 & 2.39 \\
\hline $\mathrm{V}, \%$ & 81.0 & 83.0 & 74.0 & 76.0 \\
\hline
\end{tabular}

According to a soil properties research after the fire control soil cuts were made on the background and fireinduced soils which allowed to establish type accessory of the explored soils: Near the village of Shabanovo (the fire on April 29. 2017) the soil cover is represented by sod-podzolic sandy loam gley soil on binomial deposits (on sand spread on moraine loam), and sod-podzolic sandy loam soil on binomial deposits (on thin loam, spread by sand) in Nikulino settlement in GusKhrustalny forestry (the fire on May 2. 2017) respectively.

The research program included determination of the key agrochemical, physical and chemical as well as ecological and biological parameters of the soil according to the standard procedures. The soil acid value (pH) was determined in $\mathrm{KCl}$ extract (GOST 26483-85). Content of the labile phosphorus $\left(\mathrm{P}_{2} \mathrm{O}_{5}\right)$ and potassium $\left(\mathrm{K}_{2} \mathrm{O}\right)$ was determined by Kirsanov's technique in modification of CINAO (Central research Institute of agrochemical service of agriculture) (GOST P 546502011). Content of organic matter (C, \%) by Tyurin's technique in modification of CINAO (GOST 26213-91).

Ammonifiers seeding and growing were carried out on meat-and-peptone agar (MPA), those of prototrophs on starch-and-ammonia agar (SAA), fungi - on Capek's agar, oligotrofs - on a selective medium. Soil samples gathering was carried out by a soil cane drill to the depth of 0-20 cm. Sampling was made from the center in view of accurate fire impact on a soil cover. For the research carrying out 160 soil samples were taken from each the analyzed sites and the composite samples were made for a further research.

\section{Results and their discussion}

The analysis of the selected soil samples allowed to reveal changes in soil properties not only as a result of the fire impact on different types of the forest and but also in the soil uniformity. During the primary investigation phase of soil properties change the soil acid value change was conducted which in many respects causes formation and developing of all ecological and biological processes of the soil.
Thus it was established that average soil acid value change in all the analyzed fire-induced soils equals 0.97 $\mathrm{pH}$ units. However changes of reaction size of the soil medium in the conditions of different biotopes (forests) should be noted. The soil cover of the coniferous forest where sod-podzolic sandy loam gley soil on binomial deposits was investigated is characterized by subacidic medium reaction; $\mathrm{pH}$ is equal to $5.43 \mathrm{pH}$ units. After direct fire-induced influence there is a sharp soil medium alkalizing towards a neutral reaction, $\mathrm{pH}$ makes 6.45 units. Thereby the change is 1.02 units $\mathrm{pH}$. In the broadleaved forest on sod-podzolic sandy loam soil on binomial deposits soil medium reaction makes $5.72 \mathrm{pH}$ units whereas after the influence of fire-induced factor there is a noticeable change from $0.92 \mathrm{pH}$ units up to $6.64 \mathrm{pH}$ units. Thus, it becomes apparent that at the level of different forests types and the same soil type there is sharply expressed soil medium reaction change towards the neutralizations.

As a fire byproduct there is the formation of huge ash amount caused by the mineralization of the litter and other combustible materials with a significant change in structure and organic matter quality, which in turn causes persistent changes in plant communities.

In regard to organic matter changes, it is established that its significant reduction is primarily due to the influence of fire-induced factor due to high temperatures. Since the analyzed fires are the ground fires, the temperature of burning above the soil surface and subsurface parts of the fire-induced site about $700^{\circ} \mathrm{C}$. So according to the data obtained during the research on the territory subject to the fires there is a significant reduction in the organic matter content. Average decrease in organic matter content for both types of forests and soils analyzed is $0.58 \%$. In coniferous forest on sod-podzolic soil the average organic matter content is $1.32 \%$, whereas after exposure to fire-induced factor there is a noticeable change from $0.31 \%$ to $1.01 \%$, which makes the already poor soil fertility less favorable in ecological and biological terms. The soil cover of mixed forest is also characterized by organic matter decrease in by $0.85 \%$ from $1.99 \%$ to $1.14 \%$. In the post-fire period the organic substances mobility increases, the number of 
Table 2. Soil cover physical properties changes in forest biotopes of different type under the influence of a pyrogenic factor, $\mathrm{g} / \mathrm{cm}^{3}$.

\begin{tabular}{|c|c|c|c|c|}
\hline Province & \multicolumn{2}{|c|}{ Smolensk and Moscow province of a zone of the mixed woods (subtaiga) of East European Plain } \\
\hline Landscape area & \multicolumn{2}{|c|}{ Central lake Meshchora } & \multicolumn{2}{c|}{ Gusevsky Meshchora (Gusevsko-Kolpskaya) } \\
\hline Soil & \multicolumn{2}{c|}{$\begin{array}{c}\text { Soddy strongly podsolic sandy gley on } \\
\text { binomial deposits) }\end{array}$} & \multicolumn{2}{c|}{ Soddy strongly podsolic sandy on binomial deposits } \\
\hline Wood type & \multicolumn{2}{|c|}{ Coniferous forest } & \multicolumn{2}{c|}{ The mixed wood } \\
\hline Index/option & Monitoring & After the fire To & Monitoring & After the fire To \\
\hline $\begin{array}{c}\text { Soil solid phase } \\
\text { density }\end{array}$ & 2.64 & 2.71 & 2.54 & 2.74 \\
\hline Soil density & 1.2 & 1.32 & 1.12 & 1.38 \\
\hline
\end{tabular}

the most aggressive fractions represented by fulvic acids in their composition also grows up.

As a result of forest materials combustion the ashes containing available forms of a number of nutritious elements (calcium, magnesium, potassium, phosphorus) are formed. Their maximum quantity according to the conducted research falls on the first months after the fire, but then the content of substances gradually decreases owing to features of the explored soil genesis, type of the water regime and a complex of soil migration processes. At the same time, according to the literature data, it is found that under certain conditions, with a large number of these elements, there is their preservation in the period in $2-4$ years.

The phosphate regime change is on average characterized by increase in level of security by 38.2 $\mathrm{mg} / \mathrm{kg}$. However in soils of different woods types the changes have differentiated character. So in soddypodzolic soils of the coniferous forest an average increase in phosphorus $\left(\mathrm{P}_{2} \mathrm{O}_{5}\right)$ is $54.4 \mathrm{mg} / \mathrm{kg}$ of the soil whereas in the mixed forest the increase was $21.9 \mathrm{mg} / \mathrm{kg}$ of the soil. At the same time an average potash state change increase is by $6.0 \mathrm{mg} / \mathrm{kg}$, and unlike phosphorus increase the greatest increase in potassium $\left(\mathrm{K}_{2} \mathrm{O}\right)$ takes place in soddy-podzolic soils of the mixed forest where the increase is $82.6 \mathrm{mg} / \mathrm{kg}$ whereas in of the coniferous forest soils increase in the contents was $45.4 \mathrm{mg} / \mathrm{kg}$.

As a result of a direct pyrogenic influence the hydrolytic acidity value in soddy-podzolic soils increases, the average increase is $0.11 \mathrm{mg}-\mathrm{eq} / 100$. In soddy-podzolic soils of the mixed forest the size of increase was $0.14 \mathrm{mg}-\mathrm{eq} / 100$ whereas in the coniferous forest of $0.09 \mathrm{mg}-\mathrm{eq} / 100$. Increase of calcium and magnesium on average was $0.13 \mathrm{mg}-\mathrm{eq} / 100$ and 0.21 mg-eq/100 respectively. As follows from the data provided in Table 1 the increase in contents are almost singular, but the greatest increase of Ca $0.14 \mathrm{mg}-\mathrm{eq} / 100$ and $\mathrm{Mg} 0.22$ of mg-ekv/100 falls within soddy-podzolic soils of the coniferous forest. And it is slightly less 0.11 mg-eq/100 and $0.19 \mathrm{mg}$-eq/100in the mixed forest. Degree of soil saturation the bases increases on average by 2 per cent and in soddy-podzolic soils of both forest taxons types it is identical on average to 2 per cent.

The fire can influence a soil condition from different aspects. First, the harmful influence of excessively high temperatures on a solid soil phase (tab. 2.) the size of which on average increases by $0.14 \mathrm{~g} / \mathrm{cm}^{3}$. However on soddy-podzolic soils of the mixed forest the size of the increase is $0.2 \mathrm{~g} / \mathrm{cm}^{3}$ which substantially exceeds similar increase in the coniferous forest $-0.07 \mathrm{~g} / \mathrm{cm}^{3}$.

In addition the fire's cause steady changes in the soil in terms of its physical and chemical properties, mechanical structure, the water-air and hydrothermal regime as well as soil density value. In soddy-podzolic soils which undergone pyrogenic influence, the in soil compaction increase by $0.19 \mathrm{~g} / \mathrm{cm}^{3}$ is observed. Moreover on soddy-podzolic soils of the mixed forest the increase value is $0.26 \mathrm{~g} / \mathrm{cm}^{3}$ and in the coniferous forest it is $0.12 \mathrm{~g} / \mathrm{cm}^{3}$.

Further the impact of pyrogenic influence on soils microbiological activity has been studied since microbiological characteristic traditionally is considered the most important method of biodiagnostics on the ground that microorganisms sensitively react to the changes happening in a surrounding environment. High temperature of the soil superficial horizons during and after flame passing causes a sharp increase in the content of chemically important soil properties, particularly in those of phosphorus and potassium.

It is established that pyrogenic influence sharply changes the numerical ratio of the basic microbic groups in soil complexes, so, fungi mycelium practically disappears, the number of ammonifiers and oligotrofs decreases that is connected first of all with the processes of nitric balance violation of which is necessary for these groups of microorganisms functioning. At the same time fire causes some processes activization, and promotes the biological circulation strengthening and improvement of plants nutrition in terms of the agrochemical nutrition and soil provision with ash elements.

In spite of the fact that the total number of microorganisms in the soil right after the fire decreases, nevertheless, after some time period the increase in their quantity is observed that is caused by the rapid microbic growth.

The soil microbiocenosis pool represents numerous groups of microorganisms connected by the complex system of trophic relationships. So continuous monitoring and studying the structure and variety the ecologo-trophic microorganism groups number allows to judge about the intensity and susceptibility degree of the biogenic soil horizons as well as about rate of the postfire processes of soil forest vegetation properties renewal and the trophic conditions changes in the soil biocenosis. 
Table 3. The change of microbiological structure of different type of forest biotopes under the influence of a pyrogenic factor colony forming unit (CFU) of the soil.

\begin{tabular}{|c|c|c|c|c|}
\hline Province & \multicolumn{3}{|c|}{ Smolensk and Moscow province of a zone of the mixed woods (subtaiga) of East European } \\
Plain
\end{tabular}

An average ammonifiers quantity of soddy-podzolic soils affected by the fire influence decrease on average decreases by 368.0 colony forming unit (CFU) in $1 \mathrm{~g}$ of the soil or 83.1 per cent. Proceeding from the data provided in Table 3 it is established that all like forest biotopes are subjected to changes. In the coniferous forest CFU content decrease makes $407.0 \mathrm{CFU}$ in $1 \mathrm{~g}$ of the soil or 82.4 per cent, whereas in the mixed forest it is $329.0 \mathrm{CFU}$ in $1 \mathrm{~g}$ of the soil or $83.7 \mathrm{per}$ cent. In percentage terms the ammonifiers number change is identical. Numerous groups of aerobic and anaerobic microorganisms among which there are bacteria, fungi, actinomycetes take part in the ammonification process. This particular fact causes that the soil ammonification process occurs both in the presence and absence of oxygen and in conditions of different environment reaction. The ammonification process sharply decreases only in anaerobic conditions and in the conditions of the strong acidity and a causticity of soils. The ammonification speed also depends on the temperature and humidity factors of the soil.

The prototrophs number on average decreases by 585.0 CFU in $1 \mathrm{~g}$ of the soil or by 90.2 per cent. Their reduction in the coniferous forest is $470.0 \mathrm{CFU}$ in $1 \mathrm{~g}$ of the soil or 94.8 per cent, and $700.0 \mathrm{CFU}$ in $1 \mathrm{~g}$ of the soil or 85.7 per cent in the mixed forest. Fungi on average decrease by $1876.0 \mathrm{CFU}$ in $1 \mathrm{~g}$ of the soil or by $97.4 \mathrm{per}$ cent. In the coniferous forest their reduction is 1682.0 CFU in $1 \mathrm{~g}$ of the soil or 97.5 per cent, in mixed the wood it is $2069.0 \mathrm{CFU}$ in $1 \mathrm{~g}$ of the soil or 97.3 peer cent. It is also noted that the oligotrophs number changes, however their decrease is not so vividly expressed and is on average $378.5 \mathrm{CFU}$ in $1 \mathrm{~g}$ of the soil or 42.1 per cent. The same tendency remains in the coniferous forest 497.0 CFU in $1 \mathrm{~g}$ of the soil or 49.0 per cent, and in the mixed forest the decrease is $260.0 \mathrm{CFU}$ in $1 \mathrm{~g}$ of the soil or 35.1 per cent. It connected with the fact that oligotrophs are the microorganisms making a majority of a soil cenosis, which can inhabit the soils with the low content of nutrients, and therefore in case of the analyzed fires there is the probability of their elimination lack.

\section{Conclusion}

Forest fires destroy the soil, an important component of the nature. Their complex and ambiguous influence is estimated by the whole range of factors from beginning from the specific fire characteristics and vegetation peculiarities up to the relief and structure of the soil. Changes of properties after the fire are caused by the fast mineralization of organic matter the soil, the forest floor and litterfall. Combustion products are somewhat absorbed and acquired by vegetable roots, the rest of them in the form of compounds dissolution as alkalis goes the soil rhizosphere. Within the territory subject to the fire there is the organic matter content decrease owing to the high temperature influence and increase of ash elements content $\left(\mathrm{P}_{2} \mathrm{O}_{5}, \mathrm{~K}_{2} \mathrm{O}\right)$. In the soils of forests subject to the fire, the solution alkalinization occurs due to the penetration and saturation of ash water-soluble compounds into the absorbing soil complex, which causes the shift in the environment reaction to the neutral range. The direct pyrogenic influence results in the soil physical properties change towards compaction with an increase in specific and volumetric mass. Due to the fire influence, the ecological state of soddy-podzolic soil is disturbed; there is a sharp decrease in the number of surface-active groups of micro and mesofauna, such as ammonifiers, prototrophs, fungi, oligotrophs.

\section{References}

[1] T.V. Aristovskaya, Mikrobiology of podsolicsoils, Acad. of sciences of the USSR, Soils institute named after V.V. Dokuchaev, All-Unionacad. Ag. Sc. named after V.I.Lenin, Moscow, Leningrad:Science, Leningr.department, 187 (1965).

[2] A.V. Bogorodskaya, Influence of the fire sonmicrobic soil-cover complexes of pine forests of MiddleSiberia: thesis...candidate of Biology: 03.00.16, 03.00.07, Krasnoyarsk, 195 (2006).

[3] S.H. Doerr, C. Santın, Global trends in wildfire and its impacts: perceptions versus realities in a 
changing world, Phil. Trans. R. Soc. B., 371, 1-10 (2016). DOI: 10.1098/rstb.2015.0345.

[4] Yu.L. Vorobyov, V.A. Akimov, Yu.I. Sokolov, Forest fire sin the territory of Russia: State and problems, Emercom of Russia, M.:DEKS-PRESS, 312 (2004).

[5] J. San-Miguel-Ayanz, T. Durrant, R. Boca, G. Liberta, A. Branco, D. de Rigo, D. Ferrari, P. Maianti, T. Arts Vivancos, E. Schulte, P. Loffler, Forest fires in Europe, Middle East and North Africa, 2016, Luxembourg, 126 (2017). DOI: 10.2760/17690.

[6] L.M. Fultz, J. Moore-Kucera, J. Dathe, M. Davinic, G. Perry, D. Wester, D.W. Schwilk, S. Rideout-Hanzak, Forest wildfire and grassland prescribed fire effects on soil biogeochemical processes and microbial communities: Two case studies in the semi-arid Southwest, Applied Soil Ecology, 99, 118-128 (2016).

[7] K.B. Gongalsky, Forest fires and soil fauna, The Russian acad. of sciences, Institute of environmental problems and evolution named after A.N. Severtsov, the Program of Presidium of RAS, Forestfires: the current state and problems of development, Moscow: Association of scientific publications KMK, 168 (2014).

[8] L.I. Egorenkov, Soilecology: schoolbook, Ministry of Education of the Moscow region, State education a linstitution of the higher education of the Moscow region, Moscow state regional university, Moscow: MGOU, 90 (2017).

[9] I.M. Kurbatov, E.I. Dvoynishnikova, Mikrobiology of podsolic soils and organic fertilizers, Lecture: Recommended practices for agricultural higher education institutions agr. specialties, M-tryof agriculture the USSR, Belarusian the agricultural academician, Gorky: b.and., 45 (1969).

[10] I.S. Melekhov, Nature of the forest and forestfires, Arkhangelsk: Arkhang. publishing house, type named after Sklepin, 60 (1947).

[11] A.O. Ragimov, T.A. Zubkova, M.A .Mazirov, Soil and person: the ecologo-functional interaction, Moscow, Ivanovo: FGBOUVO, Ivanovskaya of GSHA, 244 (2015).

[12] A.O. Ragimov, Ecologo-funktsional role of soils in formation of level of well being of the population of the Vladimir region: thesis... Candidate of Biology, 03.02.08, Place of thesis defence: Rus. state agrar. un-ty, Vladimir, 229 (2015).

[13] E.N. Mishustin, M.I. Pertsovskaya, V.A. Gorbov, Sanitary microbiology of the soil, Moscow: Nauka, 304 (1979).

[14] D.B. Wiedemeier, S. Brodowski, G.L.B. Wiesenberg, Pyrogenic molecular markers: Linking PAH with BPCA analysis, Chemosphere, 119, 432-437 (2015).

[15] A.N. Myers-Pigg, P. Louchouarn, R.M.W. Amon, A. Prokushkin, K. Pierce, A. Rubtsov, Labile pyrogenic dissolved organic carbon in major Siberian Arctic rivers: Implications for wildfire- stream metabolic linkages, Geophys. Res. Lett., 42, 1-9 (2015). DOI: 10.1002/2014GL062762. 